\title{
The prevalence of pathogenic bacteria and antimicrobial resistance in milk of Ettawa Grade goat
}

\author{
Andriani $^{1{ }^{1 *}}$ and W. Suwito ${ }^{2}$ \\ ${ }^{I}$ Indonesian Research Center for Veterinary Sciences, Jl. R.E. Martadinata 30, Bogor - Indonesia \\ ${ }^{2}$ Yogyakarta Assessment Institute for Agricultural Technology, \\ . Jl. Stadion Maguwoharjo No. 22 Karangsari, Wedomartani Ngemplak, \\ Sleman, Yogyakarta - Indonesia \\ *Corresponding E-mail : andri_balitvet@yahoo.com
}

Received April 28, 2017; Accepted January 03, 2018

\begin{abstract}
ABSTRAK
Kambing Peranakan Ettawa (PE) adalah kambing berpotensi dikembangkan untuk menghasilkan susu dan daging. Susu merupakan produk pangan asal ternak yang kaya nutrisi bersifat perishable food, mudah dicemari oleh mikroorganisme. Kontaminasi bakteri pathogen pada susu dapat menurunkan kualitas dan mempengaruhi kualitas organoleptic susu, serta membahayakan kesehatan manusia. Susu yang terkontaminasi bakteri antimicrobial resistance (AMR) resisten terhadap beberapa antibiotik yang dapat berpengaruh buruk terhadap respon pengobatan antibiotika pada manusia apabila menderita penyakit infeksi. Sampel susu dan produk olahan kambing PE diambil dari beberapa peternakan kambing di Kabupaten Sleman Yogyakarta telah dilakukan pengujian terhadap keberadaan bakteri pathogen serta uji resistensi terhadap beberapa macam antibiotik. Sebanyak 35 sampel susu segar kambing Ettawa dan produk olahannya (susu segar, susu bubuk, es krim, dan yogurt) diambil dari beberapa peternakan kambing di Kabupaten Sleman-Yogyakartatelah dilakukan pengujian terhadap keberadaan bakteri pathogen serta uji resistensi terhadap beberapa macam antibiotik. Hasil penelitian menunjukkan prevalensi kontaminasi bakteri pathogen Escherichia coli pada susu kambing sebesar 15\% dan bersifat resisten terhadap antibiotik ampicillin, colistin sulphate, cefixime, kanamycin, oxytetracycline, tetracycline dan sulfonamide.
\end{abstract}

Kata kunci: susu, kambing, Peranakan Ettawa, bakteri, resistensi, antibiotik.

\begin{abstract}
Ettawa Grade (PE) are potentially developed goats to produce milk and meat. Milk is food of animal that is rich in nutrients, but it is a perishable food easily contaminated by microorganisms. Contaminated pathogenic bacteria in milk can decrease the quality and has an organoleptic effect on milk, as well as endangers human health. Milk contaminated with bacteria antimicrobial resistance (AMR) in which is resistant to antibiotics, may adversely affect the response to treatment with antibiotics in humans when suffering from infectious diseases and using antibiotics in therapy. In this study Ettawa Grade's samples of fresh milk and other dairy products were taken from some of the goat farms in Yogyakarta Sleman district. The samples were tested for the presence of pathogenic bacteria and for its resistance to several kinds of antibiotics. In this study 35 Ettawa Grade's samples of fresh milk and other dairy products (fresh milk, milk powder, ice cream, and yoghurt) were taken from some of the goat farms in Sleman district-Yogyakarta. The samples were tested for the presence of pathogenic bacteria and for its resistance to several kinds of antibiotics. The result of the prevalence of pathogenic bacteria in goat fresh milk and other dairy products was 15\% Escherichia coli and had multi resistance
\end{abstract}


to multiple antibiotics, namely ampicillin, colistin sulphate, cefixime, kanamycin, oxytetracycline, tetracycline and sulfonamide.

Keywords :milk, goat, Ettawa Grade, bacteria, resistance, antibiotics

\section{INTRODUCTION}

Ettawa Grade (Peranakan Ettawa, PE) is the superior dual-purpose goat for of milk and meat goats. PE goat is the result of a crossbreeding between Kacang goat and Ettawa goat from India which are a large type and produces goat milk (Devendra and Burns, 1983). Production of goat milk can be developed to support the national milk supply. Goat milk is currently much in demand in the community, because it can be used as a cure of various diseases. These goats are potentially to be developed and is one of the featured products and pride of the people of Yogyakarta. Most people raise goats as a part-time job, many of them maintain the capacity of small or home scale.

Currently the goat milk is believed to cure various diseases by the market price reach IDR 15,000 to IDR 20,000 per liter. Goat milk has a higher protein content when compared to cow milk and as a source of minerals, calcium and phosphorus are good for baby's growth. One of the advantages of goat milk is its fat has smaller granules than cow's milk and has a relatively high proportion of short chain fatty acids so that the goat milk is easily digested (Ceballos et al., 2009).

Naturally, milk is a perishable or easily damaged product and has good nutritional value (as a protein source), but it is an excellent medium for the growth of pathogenic microorganisms that can cause foodborne disease. Contamination of microorganisms in milk decrease the quality and endanger the health of humans who consume. Pathogenic bacteria in goat milk as agents of foodborne zoonoses which can cause disease in humans include Escherichia coli, Staphylococcus aureus, Salmonella spp., Streptococcus sp. and Bacillus cereus (Suguna et al., 2012). According to Oliver et al. (2005), the prevalence of foodborne pathogens in milk is influenced by various factors such as the area for raising goat, the number of animals on the farm, health, management of breeding, variations in sampling and sample types that are evaluated, the difference in detection methodologies used, geographic location and season.

The use of antimicrobials such as antibiotics in livestock is intended for the treatment of infections, disease prevention and growth promotion. Antimicrobial use for such purposes can allow the spread of bacteria Antimicrobial Resistance (AMR), which can be transmitted to humans through milk as a food chain. AMR bacteria can cause impacts of ineffective treatment with antimicrobials or antibiotics. Currently, several types of classes of antibiotics used for the treatment of animals and is used on farms is the same class of antibiotics used for therapy in humans. The circumstance in which affect the use of antibiotics for humans to become ineffective. In Indonesia, up to now there is no regulation and monitoring on the use of AMR. However, international organizations such as World Health Organization (WHO), World Organization for Animal Health OIE and the Codex consider AMR is an important topic in the global-food safety, to support their interdisciplinary relationships to effectively address the issue of AMR. Contaminated microorganism of zoonotic foodborne pathogens and the presence of AMR bacteria in goat milk should be more attention, especially in the field of veterinary public health. Contamination of pathogenic microorganisms in milk can cause illness, while AMR contamination can lead to the treatment failure for men who consume. Consequently, to prevent illness and death associated with foodborne pathogens is a challenge that should be addressed in the field of public health. Furthermore, food safety is a global issue, and an increase in imports and exports of food products can lead to the entrance to the emergence of new diseases through food.

Studies worldwide have shown that pathogenic bacteria and AMR present in farm and their products. However, there is a paucity of data concerning the prevalence of contamination pathogenic bacteria and AMR in goat milk in the Sleman district. The objectives of this study were to identify the contaminant of pathogenic bacteria and AMR in milk to determine its quality in Ettawa Grade in Yogyakarta.

\section{MATERIALS AND METHODS}

\section{Sample collection}

This study used a sample in the form of fresh 
goat milk and various of its products from some of PE goat farms and a goat milk processing in Sleman, Yogyakarta. This study used 35 samples of fresh goat milk and various of these products from some of PE goat farms and goat milk processing in Sleman, Yogyakarta: Seyegan, Pakem, Kalasan, Cangkringan, Caturharjo, Trihanggo, Mriyan, Minggir, Ngangring, and Kemirikebo. Collected milk sample was fresh milk and other of its dairy products, those were milk powder, ice cream, and yoghurt from goat milk. Collecting the sample of $250 \mathrm{~mL}$ of fresh milk was performed in the morning. Further, the samples of fresh milk and other dairy products inserted into the ice-box and brought to the laboratory for testing.

\section{Total Plate Count (TPC)}

Calculating the TPC was done by using the official methods of AOAC (2016) with plate count. Samples of milk, yoghurt, and ice cream were taken $1 \mathrm{~mL}$, whereas for milk powder was 1 $\mathrm{g}$, and then was diluted using a $0.1 \%$ buffer peptone water (BPW, OXOID Ltd., Basingstoke, UK) up to $10^{-6}$ dilution. Furthermore, from each dilution was taken $0.01 \mathrm{~mL}$ was then inserted into sterile petri dish, then poured the liquid medium plate count agar (PCA; OXOID Ltd., Basingstoke, UK. and homogenized by means of shifting the plate horizontally or a figure number of eight and allowed to clot. The next stage was incubated at $37{ }^{\circ} \mathrm{C}$ for $24-48$ hours and all colonies were counted as TPC.

\section{Counting the Number of Staphylococcus aureus}

Counting the number of $S$. aureus was done

by official methods of AOAC International (2016). Samples of milk, yoghurt, and ice cream was taken $1 \mathrm{~mL}$, while as much as $1 \mathrm{~g}$ of milk powder, then diluted with $0.1 \%$ of BPW up to $10^{-6}$ dilution. Furthermore, from each dilution was taken $0.01 \% \mathrm{~mL}$ to put into a sterile petri dish, then poured the liquid medium mannitol salt agar (MSA; OXOID Ltd., Basingstoke, United Kingdom). Furthermore homogenized by sliding horizontally or a figure of eight, and if it has been frozen incubated at $37^{\circ} \mathrm{C}$ for $24-48$ hours. The form of counted colony was round, slippery, and yellow.

\section{Counting the Number of Coliform}

The number of coliform were counted by using official methods of AOAC (2016). Samples of milk, yoghurt, and ice cream was taken $1 \mathrm{~mL}$, while as much as 1 gof milk powder, then diluted with $0.1 \%$ BPW up to $10^{-6}$ dilution. Furthermore, from each dilution was taken $0.01 \mathrm{~mL}$ to be put into sterile petri dish, then poured the liquid medium violet red bile agar (VRBA; OXOID Ltd., Basingstoke, United Kingdom). Furthermore, it was homogenized by sliding horizontally or moved it to make a figure number of eight and allowed to be jellylike, then poured VRBA media on the surface of agar (overlay) and incubated at $37^{\circ} \mathrm{C}$ for $24-48$ hours. Counted colony was purplish red colonies surrounded by a red zone.

\section{Examination of Escherichia coli}

E. coli examination was conducted by the isolation and identification of follow instructions of Rajeev and Prasad (2010). Five mL sample of fresh goat milk, ice cream and yoghurt or $5 \mathrm{~g}$ of milk powder was added in $25 \mathrm{~mL}$ of buffer solution peptone water (BPW; OXOID Ltd., Basingstoke, United Kingdom) and then incubated at $37^{\circ} \mathrm{C}$ for 24 hour. The sample were sub cultured on media eosin methylene blue agar (EMBA; OXOID Ltd., Basingstoke, United Kingdom) and incubated at $37^{\circ} \mathrm{C}$ for 24 hours. Colonies that appeared metallic in the EMBA media were Gram stained and the colonies were biochemically tested for $E$. coli identification.

\section{Examination of Salmonella spp.}

Examination of Salmonella spp. was performed with the isolation and identification of instructions on Karshima et al. (2013). Five mL sample of fresh goat milk, ice cream and yoghurt or $5 \mathrm{~g}$ of goat milk powder poured into $25 \mathrm{~mL}$ of pre-enrichment Rapport-Vasilliadis broth and incubated at $37^{\circ} \mathrm{C}$ for 24 hours. A loopful of Rapport-Vasilliadis broth was streaked onto xylose lysine desoxycholate agar and incubated for a further 24 hours at at $37^{\circ} \mathrm{C}$ for 24 hours. Colonies that appeared characteristic pinkish colour of Salmonella with black middle on XLD media were Gram stained and furthermore, were biochemically tested for the identification of Salmonella spp.

\section{Testing Resistance}

Test of antimicrobial resistance was conducted by using disc diffusion methods. Each bacteria to be tested was grown in a medium Brain Heart Infusion (BHI; OXOID, Ltd., 
Basingstoke, United Kingdom) and incubated at $37^{\circ} \mathrm{C}$ for 24 hours. One $\mathrm{mL}$ of the BHI culture medium was dripped onto the surface of Mueller Hinton Agar (MHA; OXOID Ltd., Basingstoke, United Kingdom) was then flattened and dried in an incubator for 10 minutes. Mueller Hinton Agar (MHA; OXOID Ltd., Basingstoke, UK) that had been inoculated with bacteria were then attached by paper antimicrobial discs that the concentration was known, and then was incubated $37^{\circ} \mathrm{C}$ for 24 hours. Interpretation of the results of antimicrobial sensitivity test was performed according to the instructions of the CLSI (CLSI, 2012).

\section{RESULTS AND DISCUSSION}

The result of TPC calculation, coliforms and Staphylococcus aureus in fresh goat milk, milk powder, ice cream and yoghurt are presented in Table 1. The results obtained showed that the number of TPC and coliform in goat fresh milk was $1.7 \times 10^{4}$ and $1.4 \times 10^{4} \mathrm{cfu} / \mathrm{mL}$. The test results still indicated below the maximum limit specified in SNI No. 01- 6366-2000 on the maximum limit contamination of fresh milk, while the number of pathogenic bacteria of $S$. aureus in fresh milk $6.8 \times 10^{5} \mathrm{cfu} / \mathrm{mL}$, was greater than the maximum limit of SNI. Helene et al. (2010) and Ledenbach and Marshall (2009) had reported the fresh milk contains many microorganisms.

Staphylococcuus aureus contamination is often reported to be a problem in goat milk. The bacteria was one of the most commonly found pathogens in raw caprine and ovine milk (Marogna et al., 2012). According to Cupakova et al. (2012), milk and other dairy products were one source of $S$. aureus infections in humans. Being one of the predominant causes of food poisoning worldwide, $S$. aureus is of particular concern to the dairy industry (Oliver et al., 2009). In Europe, milk and other dairy products have been contaminated with $5 \%$ of $S$. aureus (Bianchi et al., 2014). The existence of pathogenic bacteria $S$. aureus in fresh milk can result from direct excretion of the udder suffering from clinical and subclinical mastitis or as a result in the environment during the milking process, depending on the condition of sanitation, milking equipment, and personnel who flushed (Jorgensen et al., 2005; Fagundes et al., 2010). Contamination of fresh milk can also cause the entry of microorganisms into the udder through the teat canal (Smith et al., 2007). As presented by Alexopoulos et al. (2011) that the increase in the number of $S$. aureus in goat milk is caused by poor management, such as the milker not wash their hands before milking, the goats are not cleaned before being milked, and milker does not wear a mask. Therefore milk contaminated with $S$. aureus is extremely dangerous if consumed in a raw state, as $S$. aureus can produce toxins that cause poisoning in humans. As goat and sheep's milk are often used for traditional, unpasteurized products such as raw milk cheeses, they represent a potential source of staphylococcal food poisoning (SFP). The Centers for Disease Control estimate a total number of 240,000 SFP cases per year in the US (Scallan et al., 2011). S. aureus produces enterotoxin that causes intoxication, with symptoms of nausea, vomiting, and diarrhea (Johler et al., 2015). The cases of intoxication occur due to consume food or drink that already contain the toxin. The toxin of $S$. aureus is resistant at a temperature of $110^{\circ} \mathrm{C}$ for 30 minutes and the number $10^{6}-10^{8} \mathrm{cfu} / \mathrm{mL}$ could potentially produce a toxin with a concentration $1 \mu \mathrm{g}$ (Alarcon et al., 2006). Muehlherr et al. (2003) ontheir research mentioned that $31.7 \%$ of 407 samples of goat milk contaminated with $S$. aureus. The same situation is also happening in a goat milk cheese making in Italy with $S$. aureus $1.2 \times 10^{3} \mathrm{cfu} / \mathrm{mL}$ or exceeding the standards (Foschino et al., 2002). Different circumstances reported by Taufik et al. (2011), goat milk from Bogor, which is taken directly from the udder still meets the SNI No. 016366-2000 with a mean of TPC, S.aureus and coliform were $3.74 \times 10^{3}, 1.70 \times 10^{3}$ and $0.7 \times 10^{3}$ $\mathrm{cfu} / \mathrm{mL}$, respectively. Meanwhile the microbiological quality of goat milk in Australia which meet the standards to be consumed to have average of TPC, S. aureus and coliform were 3.8 x $10^{2}, 1.4 \times 10^{2}$ and $2.3 \times 10^{2} \mathrm{cfu} / \mathrm{mL}$, respectively (Eglezos et al., 2008).

The total number of bacteria or total plate count (TPC) is one of the parameters in the standard test to determine the microbial quality of fresh milk. Milk secreted from healthy udder goats contain a number of bacteria. The increase in the number of bacteria in milk can occur due to contamination or growth of bacteria in the milk (Melisa et al., 2011). The maximum limit of the total number of bacteria in the milk category of "A" grade fresh milk is $1.0 \times 10^{2}$ to $1.0 \times 10^{4} \mathrm{cfu} /$ $\mathrm{mL}$. Determination of microbiological quality of goat milk can also be done with mastitis test. Goat milk with mastitis test positive score 2 and 3 have 
Table 1. TPC, Coliforms and S. aureus in Fresh Milk and Other Dairy Products

\begin{tabular}{lcccccc}
\hline \multirow{2}{*}{ Type of Milk } & \multicolumn{5}{c}{ Mean $(\mathrm{cfu} / \mathrm{mL})$} \\
\cline { 2 - 7 } & TPC & SNI* & Coliform & SNI* & S. aureus & SNI* \\
\hline Fresh milk & $1.7 \times 10^{4}$ & $1.0 \times 10^{6}$ & $1.4 \times 10^{4}$ & $2.0 \times 10^{1}$ & $6.8 \times 10^{5}$ & $1.0 \times 10^{2}$ \\
Milk powder & $5.5 \times 10^{4}$ & $5.0 \times 10^{4}$ & 0 & $1.0 \times 10^{1}$ & 0 & $1.0 \times 10^{2}$ \\
Ice cream & $5.5 \times 10^{4}$ & $1.0 \times 10^{5}$ & 0 & $3.0 \times 10^{0}$ & 0 & $1.0 \times 10^{2}$ \\
Yoghurt & $5.9 \times 10^{4}$ & $1.0 \times 10^{5}$ & 0 & $3.0 \times 10^{0}$ & 0 & $1.0 \times 10^{2}$ \\
\hline
\end{tabular}

*SNI (Indonesian National Standard) No.01-6366-2000 on the maximum limit contamination of fresh milk

a mean of TPC, S. aureus and coliform still below the SNI No. 01-6366-2000 (Setiawan et al., 2013), whereas the increase in somatic cell count may occur in old goat but not related to the type of bacteria that cause mastitis (Suguna et al., 2012).

Salmonellosis is the most common foodborne bacteria, the disease around the world, especially in the developing countries (Cupakova et al.,. 2012). However, dairy products are recognized as one of the main source of Salmonella contamination, which can occur from either feces or unhygienic environment encountered in the farms vicinity (Lanzas et al., 2010). Salmonella causes diarrhea, cramps, vomiting, and often fever. Salmonellosis is caused by consuming raw milk or pasteurized milk and dairy products with the imperfect heating (Karshima et al., 2013). Escherichia coli and Salmonella spp. are bacterial contaminants that can be harmful to humans, causing the typhus disease and can cause diarrhea, fever and sometimes with vomiting (Pires et al., 2014). As Salmonella spp. are considered a potential foodborne pathogen, their presence even in threshold levels is not acceptable, considering the effects rendered on consumers. The results of the examination of E. coli and Salmonella spp. in goat fresh milk and other dairy products are presented in Table 2.

The test results of fresh milk from the PE goat farms in Pakem, Seyegan and Trihanggo was found contaminated with $E$. coli with prevalence of 3/20 (15\%), while testing of Salmonella spp., showed negative in all samples. Escherichia coli contamination in fresh milk can occur through animal feces or goat's urine that contaminate goat milk especially during milking (Suguna et al., 2012). Escherichia coli contamination will occur if goat is not cleaned when it is milked and dirty environmental cages. Apart from unclean goats when it is milked and dirty environment, the source of water used to wash the udder can be a source of contaminants (Suwito and Andriani, 2012; Salman and Hamad. 2011). Based on the examination, drink goat milk in its raw state is not recommended, to avoid the occurrence of intoxication after drinking milk as well as suffering from foodborne disease. The presence of $E$. coli in raw milk causes milk is not safe for consumption. This is consistent with the statement made by Cupakova et al. (2012) that E. coli in milk can be harmful to consumers. Therefore, drinking milk in its raw state is very dangerous, it is pasteurized or boiled before drinking is a way to eliminate pathogenic bacteria. Moreover, it also needs to improve aspects of good manufacturing practice (GMP) to produce fresh milk and processed products that have good quality, as well as to improve sanitation and hygiene during the milking process. Thus, fresh milk and other dairy products manufactured are safe to eat because humans who consume are protected from infectious disease and antimicrobial resistance that can lead to failure of antibiotic therapy in human (Oliver et al., 2005; Wubete, 2009).

Sensitivity test on $E$. coli isolated from fresh goat milk to several antibiotics are presented in Table 3. Escherichia coli from fresh goat milk from the district of Seyegan, Pakem, and Trihanggo has been resistant to the antibiotic ampicillin, colistin sulphate, cefixime, kanamycin, oxytetracycline, tetracycline, sulfonamide. This is probably caused by the use of these antibiotics freely on the scope of the farm. This happens because antibiotics are easily available in the market to be sold freely, whereas resistance to colistin sulphate likely caused by additional feed 
Table 2. Isolation and identification of E. coli and Salmonella spp. in Goat Fresh Milk and Processed Products

\begin{tabular}{llll}
\hline \multirow{2}{*}{ Location } & Type of Sample & \multicolumn{2}{c}{ Isolation and Identification } \\
\cline { 2 - 4 } Kalasan & Fresh milk & E. coli & Salmonella spp. \\
& Powder milk & Negative & Negative \\
Pakem & Fresh milk & Negative & Negative \\
& Powder milk & Positive & Negative \\
Seyegan & Yoghurt & Negative & Negative \\
& Fresh milk & Negative & Negative \\
Cangkringan & Powder milk & Positive & Negative \\
Caturharjo & Ice cream & Negative & Negative \\
Trihanggo & Fresh milk & Negative & Negative \\
Mriyan & Fresh milk & Negative & Negative \\
Minggir & Fresh milk & Negative & Negative \\
Ngangring & Fresh milk & Positive & Negative \\
Trihanggo & Fresh milk & Negative & Negative \\
Kemirikebo & Powder milk & Negative & Negative \\
Kemirikebo & Powder milk & Negative & Negative \\
Kemirikebo & Powder milk & Negative & Negative \\
Kemirikebo & Powder milk & Negative & Negative \\
Kemirikebo & Powder milk & Negative & Negative \\
\hline & Powder milk & Negative & Negative \\
\hline & Powder milk & Negative & Negative \\
\hline & Negative & Negative \\
\hline
\end{tabular}

given continuously in goats. Colistin sulphate is included in antibiotics that are often added to animal feed as a feed additive with the aim to improve feed conversion.

The use of feed additives in the long run leads to the occurrence of resistance to these antibiotics. The resistance against antibiotics such as, cefixime, kanamycin, oxytetracycline, tetracycline and sulfonamides can be caused by the freely use by farmers regardless of right dosage. Resistance is a property of no disruption of bacterial cell life by antibiotics (Julian and Davies, 2010). Antibiotic resistance is divided into two: the natural resistance and acquisition resistance. Natural resistance is a condition where antibiotics are not able to work in the spectrum of the usual doses or higher. Bacteria that is previously sensitive to a particular antibiotic and then becomes resistant, it is called acquisition resistance (Julian and Davies, 2010). The emergence of $E$. coli resistance to several antibiotics as E.coli pathogenic bacteria and AMR in goat milk are problems in the public health. According to Wubete (2009), antibiotic sensitivity patterns of isolates are useful to categorize their opportunistic pathogens in food products, so the categorization is necessary to minimize the risk of pathogenic bacterial infection and AMR in humans as foodborne agent through milk and other dairy products.

\section{CONCLUSION}

The prevalence of contamination of pathogenic bacteria of E. coli in Ettawa Grade's fresh milk is $15 \%$, while Salmonella spp. is not 
Table 3. Sensitivity of E. coli Derived from Goat Fresh Milk to Several Antibiotics.

\begin{tabular}{|c|c|c|c|c|c|c|}
\hline \multirow[b]{3}{*}{ Antibiotic } & \multicolumn{6}{|c|}{ Inhibition Zona (mm) } \\
\hline & \multicolumn{3}{|c|}{ MIC } & \multicolumn{3}{|c|}{ Isolates } \\
\hline & $\mathrm{S}$ & I & $\mathrm{R}$ & EP & ES & ET \\
\hline Streptomisin $(10 \mu \mathrm{g})$ & $\geq 15$ & $14-12$ & $\leq 11$ & 12 & 17 & 18 \\
\hline Chloramphenikol $(30 \mu \mathrm{g})$ & $\geq 18$ & $13-17$ & $\leq 12$ & 21 & 26 & 25 \\
\hline Amoxicicilin $(30 \mu \mathrm{g})$ & $\geq 18$ & $14-17$ & $\leq 13$ & 14 & 25 & 16 \\
\hline Oxytetracycline $(30 \mu \mathrm{g})$ & $\geq 19$ & $15-18$ & $\leq 14$ & 17 & 23 & 0 \\
\hline Ampicilin $(10 \mu \mathrm{g})$ & $\geq 17$ & $14-16$ & $\leq 13$ & 8 & 0 & 0 \\
\hline Gentamicin $(10 \mu \mathrm{g})$ & $\geq 15$ & $13-14$ & $\leq 12$ & 18 & 18 & 18 \\
\hline Enrofloxacin $(5 \mu \mathrm{g})$ & $\geq 21$ & $16-20$ & $\leq 15$ & 20 & 19 & 23 \\
\hline Colistin Sulfate $(10 \mu \mathrm{g})$ & $\geq 15$ & $13-14$ & $\leq 12$ & 0 & 0 & 10 \\
\hline Cefixime $(5 \mu \mathrm{g})$ & $\geq 19$ & $16-18$ & $\leq 15$ & 0 & 23 & 18 \\
\hline Tetracycline $(30 \mu \mathrm{g})$ & $\geq 19$ & $15-18$ & $\leq 14$ & 15 & 22 & 8 \\
\hline Kanamycin $(30 \mu \mathrm{g})$ & $\geq 18$ & $14-17$ & $\leq 13$ & 18 & 12 & 20 \\
\hline Ciprofloxacin $(5 \mu \mathrm{g})$ & $\geq 21$ & $16-20$ & $\leq 15$ & 24 & 30 & 27 \\
\hline Neomycin $(30 \mu \mathrm{g})$ & $\geq 18$ & $14-17$ & $\leq 13$ & 14 & 14 & 15 \\
\hline Sulfonamide (S $300 \mu \mathrm{g}$ ) & $\geq 17$ & $13-16$ & $\leq 12$ & 23 & 21 & 7 \\
\hline
\end{tabular}

$\mathrm{S}=$ Sensitive, $\mathrm{I}=$ Intermediate, $\mathrm{R}=$ Resistant, $\mathrm{EP}=E$. coli originated from Pakem, $\mathrm{ES}=E$. coli originated from Seyegan, ET $=E$. coli originated from Trihanggo

found in all samples. The emergence of AMR bacteria E.coli in Ettawa Grade milk has multi resistance to some antibiotics, it is very important to enhance the quality of goats handling and farming in accordance with good agricultural practices (GAP) . The use of antibiotics as a treatment for infectious diseases need to be supervised by a veterinarian, whereas the use of antimicrobials as feed additive in a long time requires necessary consideration.

\section{REFERENCES}

Alarcon, B., B. Vicedo, and R. Aznar. 2006. PCRbased procedures for detection and quantification of Staphylococcus aureus and their application in food. J. Appl. Microbiol. 100(2):352-364.

Alexopoulos, A., G. Tzatzimakis, E. Bezirtzoglou, S. Plessas, E. Stavropoulou, E. Sinapis and Z. Abas. 2011. Microbiological quality and related factors of sheep milk produced in farms of NE Greece. Anaerobe. 17:276-279.

AOAC (Association of Official Analytical
Chemist). 2016. Official Methods of Analysis, $20^{\text {th }}$ Ed. Association of Official Analytical Chemist. Washington. DC.

Bianchi, D.M., S. Gallina, A. Bellio, F. Chiesa, T. Civera and L. Decastelli. 2014. Enterotoxin gene profiles of Staphylococcus aureus isolated from milk and dairy products in Italy. Lett. Appl. Microbiol. 58:190-196.

Ceballos, A., J. Sanchez, H. Stryhn, J.B. Montgomery, H.W. Barkemaand and J.J. Wichtel. 2009. Meta-analysis of the effect of oral selenium supplementation on milk selenium concentration in cattle. J. Dairy Sci. (92):324-342.

CLSI (The Clinical and Laboratory Standards Institute). 2012. Performance Standards for Antimicrobial Susceptibility Testing; Twenty-Fourth Informational Supplement.

Cupáková, S., M. Pospíšilová, R. Karpíšková, B. Janštová and L. Vorlová. 2012. Microbiological quality and safety of goat's milk from one farm. Acta Univ. Agric. Et Silvic. Mendel. Brun. LX(6):33-38. 
Devendra, C. and M. Burns. 1983. Goat Production in the Tropics. Farnham Royal: Commonwealth Agricultural Bureaux.

Eglezos, S., B. Huang, A. Gary, Dykes, N. Fegan, K. Bell and E. Stuttard. 2008. A survey of microbiological quality of frozen unpasteurised goats' milk in Queensland, Australia. The Aust. J. Dairy Technol. 63(3):79-81.

Fagundes, H., L. Barchesi, A.N. Filho, L. M. Ferreira and C.A.F. Oliveira. 2010. Occurrence of Staphylococcus aureus in raw milk produced in dairy farms in Sao Paulo state, Brazil. Brazilian J. Microbiol. 41:376380 .

Foschino, B.R., A. Invernizzi, R. Barucco and K. Stradiotto. 2002. Microbial composition, including the incidence of pathogens, of goat milk from the Bergamo region of Italy during a lactation year. J. Dairy Res. 69: 213-225.

Johler, S., P. Giannini, M. Jermini, J. Hummerjohann, A. Baumgartner and R. Stephan. 2015. Further evidence for staphylococcal food poisoining outbreaks caused by egc-encoded enterotoxins. Toxins 7:997-1004.

Jorgensen, H.J., T. Mork, D.A. Caugant, A. Kearns and L.M. Rørvik. 2005. Genetic variation among Staphylococcus aureus strains from Norwegian bulk milk. Appl. and Environ. Microbiol. 71:8352-8361.

Julian, D. and D. Davies. 2010. Origins and evolution of antibiotic resistance. Microbiol. Mol. Biol. Rev. 74(3):417-433.

Karshima, N.S., V.A. Pam, S.I. Bata, P.A. Dungand and N.D. Paman. 2013. Isolation of Salmonella species from milk and locally processed milkproducts traded for human consumption and associated riskfactors in Kanam, Plateau state, Nigeria. J. Anim Prod Adv. 3:69-74.

Lanzas, C., L.D. Warnick, K.L. James, E.M. Wright, M. Wiedmann and Y.T. Grohn. 2010. Transmission dynamics of a multidrug-resistance Salmonella typhimurium outbreak in dairy farm. FoodBorne Path. Dis. 4:467-474.

Ledenbach, L.H. and R.T. Marshall. 2009. Microbiological Spoilage of Dairy Products. In :Compendium of the Microbiological Spoilage of Foods and Beverages, Food Microbiology and Food Safety. W.H. Sperber, M.P. Doyle (eds.). Springer Science
Business Media. LLC.

Marogna, G., C. Pilo, A. Vidili, S. Tola, G. Schianchi and S.G. Leori. 2012. Comparison of clinical findings, microbiological results, and farming parameters in goat herds affected by recurrent infectious mastitis. Small Rum. Res. 102:74-83.

Melisa, A., P. Hinds, S. Hurditt, P. Miller, D. Mc Growder and R. Alexander-Lindo. 2011. The microbial content of unexpired pasteurized milk from selected supermarkets in a developing country. Asian Pac. J. Trop. Biomed. 1(3):205-211.

Muehlherr, J.E., C. Zweifel, S. Corti, J.E. Blancoand and R. Stephan. 2003. Microbiological quality of raw Goat's and Ewe's bulk tank milk in Switzerland. J. Dairy Res. 86:3849-3856.

Oliver, S.P., B.M. Jayaraoand and R.A. Almeida. 2005. Review : Foodborne pathogens in milk and the dairy farm environment: Food safety and public health implications. Foodborne Path. Dis. 2(2):115-129.

Oliver, S.P, K. Boor, S.C. Murphy and S.E. Murinda. 2009. Food safety hazards associated with consumption of raw milk. Foodborne Pathog. Dis. 6:793-806.

Pires, S.M., A.R. Vieira T. Hald and D. Cole. 2014. Source Attribution of Human Salmonellosis: An Overview of Methods and Estimates. Foodborne Pathog. Dis. 11(9):667-676.

Rajeev K. and A. Prasad. 2010. Detection of $E$. coli and Staphylococcus in Milk and Milk Products in and around Pantnagar. Veterinary World. 3(11):495-496.

Salman, A.M.A. and I.M. Hamad. 2011. Enumeration and identification of Coliform bacteria from raw milk in Khartoum State, Sudan.J. Cell Anim. Biol. 5(7):121-128.

Scallan E., R.M. Hoekstra, F.J. Angulo, R.V. Tauxe, M.A. Widdowson and S.L. Roy. 2011. Foodborne illness acquired in the United States - major pathogens. Emerg. Infect. Dis. 17:7-15.

Setiawan, J., R.R.A. Maheswari and B.P. Purwanto. 2013. Sifat fisik dan kimia, jumlah sel somatic dan kualitas mikrobiologis susu kambing Peranakan Ettawa. Acta Vet. Indonesiana. 1(1):32-43.

Smith, K., K. Peter, H. Daniela and S. Melchior. 2007. Food borne pathogenic microorganisms and natural toxins. Food drug Administration center food safety. 
Appl. Nut. 10:119-150.

Suguna, M., R. Bhat and W.A. Wan Nadiah. 2012. Microbial quality evaluation of goat milk collected from small-scale dairy farms in Penang Island. Malaysia. Int. Food Res. J. 19(3):1241-1245.

Suwito, W. and Andriani. 2012. Teknologi penanganan susu yang baik dengan mencermati profil mikroba susu sapi di berbagai daerah. J. Penelitian Pascapanen Pertanian. 9(1):35-44.
Taufik, E., G. Hildebrandt, J.N. Kleer, T.I. Wirjajanto, K. Kreausukon, K.H. Zessin, M.P.O. Baumann and F.H. Pasaribu. 2011. Microbiological quality of raw goat milk in Bogor Indonesia. Media Peternakan. 34:105-111.

Wubete, Y. 2009. Bacteriological quality of bovine milk in small holder dairy farms in Debre-Zeit, Ethiopa. Thesis: Addis Ababa University. 